\title{
Design Processes and Constructive Ergonomics
}

\section{Broberg, Ole}

\section{Published in:}

Proceedings of the 33rd European Conference on Cognitive Ergonomics (ECCE 2015)

Link to article, DOI:

$10.1145 / 2788412.2788415$

Publication date:

2015

Document Version

Peer reviewed version

Link back to DTU Orbit

Citation (APA):

Broberg, O. (2015). Design Processes and Constructive Ergonomics. In Proceedings of the 33rd European Conference on Cognitive Ergonomics (ECCE 2015) [Article No. 4] Association for Computing Machinery. https://doi.org/10.1145/2788412.2788415

\section{General rights}

Copyright and moral rights for the publications made accessible in the public portal are retained by the authors and/or other copyright owners and it is a condition of accessing publications that users recognise and abide by the legal requirements associated with these rights.

- Users may download and print one copy of any publication from the public portal for the purpose of private study or research.

- You may not further distribute the material or use it for any profit-making activity or commercial gain

- You may freely distribute the URL identifying the publication in the public portal

If you believe that this document breaches copyright please contact us providing details, and we will remove access to the work immediately and investigate your claim 


\title{
Design Processes and Constructive Ergonomics
}

\author{
Ole Broberg \\ Technical University of \\ Denmark \\ DTU Management Engineering \\ Building 424, 2800 Lyngby \\ Denmark \\ obro@dtu.dk
}

\begin{abstract}
This paper discusses some central issues in the concept of constructive ergonomics. It does so by reflecting on experiences from ergonomics intervention projects carried out in Denmark. Constructive ergonomics has a huge potential as a new way to go for ergonomics research and practice. However, many challenges are to be overcome. They relate among others to education and training of ergonomist, and the cultural and institutional setting of ergonomics in specific countries.
\end{abstract}

\section{Author Keywords}

Constructive ergonomics; design processes; participatory design; simulation; role of ergonomists.

\section{INTRODUCTION}

In a book edited by Pierre Falzon (Falzon 2015a) the community of French ergonomics is launching a manifesto on the concept of constructive ergonomics. The aim of this paper is to outline some reflections on experiences gained in a Scandinavian country in relation to central issues in the manifesto.

Constructive ergonomics focuses basically on how to design work systems that will enable and promote the development of skills, practices and methodologies in individuals, collectives and organizations. Hence, development should be the purpose of ergonomic interventions indicating a new role for ergonomists (Falzon 2015b).

Based on several ergonomics interventions projects in Denmark I will briefly reflect on the following that are also key issues in the constructive ergonomics manifesto: 1)

Permission to make digital or hard copies of part or all of this work for personal or classroom use is granted without fee provided that copies are not made or distributed for profit or commercial advantage and that copies bear this notice and the full citation on the first page. Copyrights for third-party components of this work must be honored. For all other uses, contact the Owner/Author.

Copyright is held by the owner/author(s).

ECCE 2015, July 01-03, 2015, Warsaw, Poland

ACM 978-1-4503-3612-3/15/07.

http://dx.doi.org/10.1145/2788412.2788415
Understanding design processes that results in new or redesigned work systems, 2) participatory work systems design, 3) methodologies to simulate future work systems as part of a design process, and 4) the role of ergonomists in design projects. However, because of cultural and institutional differences between many French-speaking countries and the Scandinavian countries I will start by shortly clarify the question: Who is the ergonomist? The answer to this question might have great impact on how constructive ergonomics can be promoted in a country. It will also impact on the education and training of constructive ergonomists.

\section{WHO IS THE ERGONOMIST?}

In Denmark there is no formal ergonomics education and profession. The closest you can get is the field of occupational health and safety (OHS). In this field there is different continuing education schemes including masters programs. The OHS field is defined in a broad sense, including traditional safety and health issues, work organization as well as psychosocial issues. Hence, the professionals in the field have different educational backgrounds and include engineers, technicians, physiotherapists, physicians, and psychologists. The OHS profession is practiced in companies and specialized occupational health consultancies. In a company the OHS professional may work in a dedicated OHS department or as part of a HR department. The occupational health consultancies offer services to companies and organizations to help handling OHS issues. This service is linked to the Danish work environment legislation. A company or organization may be legally forced to hire an occupational health consultancy if they get an order from the governmental Labor Inspection.

The main characteristic of this kind of "Danish ergonomists" is that they are mostly concerned with the wellbeing of workers, and only to a minor degree with the systems performance.

\section{DESIGN PROCESSES}

In recent years the focus on different kind of design processes has increased within ergonomics. The idea is to integrate ergonomics into early phases of design projects, which results in new or redesigned work systems. The 
overall aim is to promote human well-being and systems performance. However, for ergonomists to undertake this task they need to understand the dynamics of design processes and projects. Design processes are conceived in many different ways. From the normative point of view stage gate models are being promoted indicating a rational and linear design process. From an analytical point of view there are more candidates, including Bucciarelli's notion of design being a social process involving ambiguity and negotiation processes between different object worlds (Bucciarelli 1994). There is the Science and Technology Studies oriented idea of network building processes between human and non-human actors (e.g. Law \& Callon 1992 and Latour 1987).

Based on research projects within public offices, hospitals and industrial manufacturing companies design processes may be conceptualized as complex configuration processes. Project managers, designers and other decision makers struggle with the configuration and alignment of all the heterogeneous elements that are part of design processes, including people, physical objects, constraints, interests, technology, knowledge, and budgets.

From an ergonomics point of view it is my experience that ergonomists have little insight in the dynamics and work practices of design projects, and hence it is hard to work on integrating ergonomics into these processes. This points to a need for educating and training ergonomists in order to have a better understanding of design processes and the options and methods for integrating ergonomics.

\section{PARTICIPATORY DESIGN}

Participatory design and ergonomics is aimed at having the end-user, the worker, to participate in the design or redesign of products, services and systems. Thereby knowledge of how work is actually done and what could be the demands for a new work system are included in the design process.

Based on participatory design projects within the public hospital sector in Denmark, I have learned that healthcare workers have much to contribute to design or redesign of hospitals and departments in order to improve work systems. Setting up and facilitating meetings between healthcare workers and architectural and engineering designers in workshops using methods like design games are possible (Broberg \& Edwards 2012). However, such activities are often isolated events in a large-scale design project, and the challenge is to transfer and translate the outcome of participatory design events to the overall design process to have an impact there. So, ergonomists may be able to stage and facilitate participatory design events but how do they handle the transfer of the outcome so it will have an impact on the overall design project?

\section{SIMULATION OF FUTURE WORK SYSTEMS}

Simulation of future work systems is another way of including the real-work knowledge and demands of future users into the design process. "Simulations are at the heart of the ergonomic approach of design” (Barcellini et al. 2015).

Using scenario-based tabletop simulations in a case of design of a new outpatient clinic at a hospital proved to be a very powerful way of worker participation in design (Broberg et al. 2012). A group of physicians, nurses and secretaries from the existing clinic were able to develop a quite new concept for a new outpatient clinic. Tabletop simulations with very simple objects like cardboard boxes and LEGO figures turned out to enable the development of a new work system supporting knowledge sharing, supervision of junior physicians, task coordination, reducing patient time spent in the clinic, and optimizing workspace utilization. In this case the healthcare workers did not only test and modify a proposal from the designers. They were able to innovate the work system by help of simulation activities and they were able to learn from this experience.

\section{THE ROLE OF ERGONOMISTS}

The preceding issues all relate to both research and practice within ergonomics. From a research point of view it is often stipulated that when the researchers in an ergonomics intervention project have left the scene after demonstrating how the intervention could be done, it is up to the professional ergonomist to take over in the next case (Seim et al. 2014). According to my experiences there is a big gap between researchers prescriptions of the ergonomist's role and the actual work of ergonomists. Based on experiences from Denmark, it is very difficult for ergonomists to get involved in the early phases of design projects. Even within a major engineering consultancy firm having a department of OHS consultants, the latter had very hard times in getting included in architectural and engineering consultancy contracts done by other departments within the company (Hall-Andersen \& Broberg 2014). One of the main obstacles was the invoicing system in which every consultant had to bill his work hours to a client contract. The OHS department and OHS consultants were not able to sell their services internally to get some work hours on a client contract.

“.. the role played by an ergonomist is never neutral” (Béguin 2015). I agree. However, some times it seems that ergonomists themselves and other stakeholders in design projects do not agree. Many ergonomists consider themselves, and are being expected to act as, neutral experts. Based on a study of how an OHS consultant successfully took part in a design project of new check-in desks in an airport, we coined the term 'political reflective navigator' for the role she played (Broberg \& Hermund 2004). She had an (political) agenda of ensuring good and developmental working conditions for the personnel to work in the desks. When pursuing this agenda she was reflective in when to use what kind of knowledge and expertise in the design process. And she was able to navigate in the complex landscape of project managers, 
designers and decision makers in order to promote her agenda by help of alliances. When reporting this finding and the term of political reflective navigator back to a group of OHS consultants they surely did not like it, especially the term 'political'. For me, this points to the professional selfawareness of ergonomists as a potential barrier to promote constructive ergonomics.

In a subsequent project we worked actively with a group of OHS consultants to train them in a new role, termed 'workspace designer' (Seim et al. 2014). It was quite successful to set up a "learning by doing" scheme in which OHS consultants were introduced to new ways of working and new methods, and hereafter tried to implement the methods in real consultancy tasks getting the hands-on experiences from their daily work.

In another project we studied if and how OHS consultants could promote learning to take place in the client organization (Broberg \& Hermund 2007). This would mean that the OHS consultant not only helped with a work system design issue but also enabled the client to learn from the consultancy and thereby being able to develop a new work practice concerning OHS issues. We concluded that learning took place when the OHS consultant was working across organizational departments within the client organization and facilitated meetings between persons from different parts of the organization. We also concluded that the OHS consultant should carefully choose boundary objects (Star \& Griesemer 1989) as learning devices between different communities of practice (Wenger 2000). Some boundary objects work better than others in promoting learning and collaborative work system design processes (Broberg \& Hermund 2007).

This points to the central question of how to educate and train ergonomists to become constructive ergonomists?

\section{CONCLUSION}

There is a great potential in the constructive ergonomics approach. It outlines a new way to go for ergonomics research and practice that are aiming at setting a new agenda for design of work systems. However, the way to go will look different in different cultural and institutional settings.

\section{REFERENCES}

1. Barcellini, F., Van Belleghem, L., Daniellou, F. (2015). Design projects as opportunities for the development of activities. In P. Falzon (Ed.), Constructive Ergonomics (pp. 187-203). Boca Raton, FL: CRC Press.

2. Béguin, P. (2015). The design of instruments viewed as a dialogical process of mutual learning. In P. Falzon (Ed.), Constructive Ergonomics (pp. 143-156). Вoca
Raton, FL: CRC Press.

3. Broberg, O., \& Hermund, I. (2004). The OHS consultant as a 'political reflective navigator' in technological change processes. International Journal of Industrial Ergonomics, 33, 315-326.

4. Broberg, O., \& Hermund, I. (2007). The OHS consultant as a facilitator of learning in workplace design processes: Four explorative case studies of current practice. International Journal of Industrial Ergonomics, 37, 810-816.

5. Broberg, O., Edwards, K. (2012). User-driven innovation of an outpatient department. Work, 41, 101106.

6. Broberg, O., Edwards, K., Nielsen, J., Hartmann, T.S., Momme, E., Sperschneider (2012). Scenario-based table top simulations. Proceedings from 44th Annual Nordic Ergonomics Society Conference, Stockholm.

7. Bucciarelli, L. L. (1994). Designing Engineers. Cambridge: The MIT Press

8. Falzon, P. (2015a). Constructive Ergonomics. Boca Raton FL: CRC Press.

9. Falzon, P. (2015b). Introduction. In P. Falzon (Ed.), Constructive Ergonomics (pp. vii-xxii). Boca Raton, FL: CRC Press.

10. Hall-Andersen, L. B., \& Broberg, O. (2014). Integrating ergonomics into the engineering design of a hospital sterile processing plant: The role of objects. Applied Ergonomics, 45, 647-654.

11. Latour, B. (1987). Science in action. Cambridge MA: Harvard University Press.

12. Law, J., \& Callon, M. (1992). The life and death of an aircraft: A network analysis of technical change. In W. E. Bijker \& J. Law (Eds.), Shaping technology/building society: studies in sociotechnical change (pp. 21-52). Cambridge MA: MIT Press.

13. Seim, R., Broberg,O., Andersen,V. (2014). Ergonomics in design processes: The journey from ergonomist towards workspace designer. Human Factors and Ergonomics in Manufacturing \& Service Industries, 24(6), 656-670.

14. Star, S. L., Griesemer, J.R. (1989). Institutional ecology, 'translations' and boundary objects: Amateurs and professionals in Berkeley's Museum of Vertebrate Zoology. Social Studies of Science, 19, 387-420.

15. Wenger, E. (2000). Communities of practice and social learning systems. Organization, 7(2), 225-246 